\title{
Heavy Metal Enrichment and Remediation Potential of Jatropha curcas Linn Seedlings in Dumpsite Contaminated Soil
}

\author{
*AKINTOLA, OO; ABODURIN, EK; BODEDE, IA \\ Forestry Research Institute of Nigeria, P.M.B 5054 Jericho Hill, Ibadan, Oyo State, Nigeria \\ *Corresponding Author Email: toyinakintola73@gmail.com
}

\begin{abstract}
Heavy metals contamination in water, soil, and plants is a frightening portent around the globe and their bio- amplification through the food chain can cause dangerous health hazards. This study assessed the ability of Jatropha curcas seedlings to uptake and distributes heavy metals totheir tissue parts from dumpsite soil. Heavy metals concentration in dumpsite soils before plantings were $\mathrm{Cu}$ (48.01 - 356.71), $\mathrm{Zn}$ (39.99 - 437.88), $\mathrm{Pb}$ (28.42 - 260.48), $\mathrm{Cd}(0.69$ - 9.75), $\mathrm{Co}(16.89-27.22)$ and $\mathrm{Cr}(20.01-30.11)$ while their concentration after planting were $\mathrm{Cu}(7.01-221.22)$, Zn $(6.22$ $301.99), \mathrm{Pb}(10.26-225.98), \mathrm{Cd}(0.48-4.01), \mathrm{Co}(7.09-14.61)$ and $\mathrm{Cr}(9.56-15.89)$ in $\mathrm{mg} / \mathrm{kg}$. Concentration of heavy metal $(\mathrm{mg} / \mathrm{kg})$ in roots were $\mathrm{Cu}(12.99$ - 28.99), $\mathrm{Zn}(11.97-30.22), \mathrm{Pb}(9.51-17.31)$. Cd $(0.19-0.99), \mathrm{Co}(6.01-8.56)$ and $\mathrm{Cr}(8.22$ - 9.56) and shoots were $\mathrm{Cu}$ (25.22- 46.21), $\mathrm{Zn}$ (26.09 - 48.01), $\mathrm{Pb}(11.46$ - 17.31), $\mathrm{Cd}(0.25$ - 1.23). $\mathrm{Co}$ (9.22 $-12.98)$ and $\mathrm{Cr}(10.98-14.01)$ showed the uptake and enrichment level of heavy metals in the plants. Enrichment and distribution factors were 0.10 to 1.92 and 1.21 to 2.17 respectively. Reduction in the concentration of heavy metals after planting indicated their enrichment in the plant tissues. Medium to high values of enrichment and distribution factors indicated ability of Jatropha carcass seedlings to uptake heavy metals from the soil and distributes them into its parts. This study has further proven the potency of Jatropha curcas seedlings as phytoextractor plants.
\end{abstract}

\section{DOI:https://dx.doi.org/10.4314/jasem.v23i8.8}

Copyright: Copyright $(\mathrm{C}) 2019$ Akintola et al. This is an open access article distributed under the Creative Commons Attribution License (CCL), which permits unrestricted use, distribution, and reproduction in any medium, provided the original work is properly cited.

Dates: Received: 20 May 2019; Revised: 27 July 2019; Accepted 31 July 2019

Keywords: Contamination, enrichment, heavy metals, soil

Contamination of heavy metals from mining, smelting, tanning industries, electroplating, manufacturing, agricultural and waste disposal technologies in the environment is a major global concern despite their toxicity and threat to human life and environment ((Shanker et al., 2005; Yruela, 2005; Ceribasi andYetis, 2001; Hernandez-Ochoa et $a l ., 2005)$. Phytoremediation is the act of using green plants and their associated microbes to remove environmental contaminants or to make them harmless; (Kambhampati and Vu, 2013). It is a plantbased technology that employs the use of natural processes where the plants are combined with microbial rhizosphere to vitiate and take up pollutants both organic and inorganic thus, heightening environmental clean-up (Pilon-Smiths, 2005; Cook and Hesterberg, 2013). Most organic pollutants that are released into the environment are anthropogenic and toxic and carcinogenic (Meagher, 2000). Specific plants and wild species (accumulators) that are used in this technique are effective in accumulating high amounts of toxic heavy metals (Ghosh and Singh, 2005; Brunet et al., 2008). They accumulate heavy metals at higher concentrations ( $\geq 100$ times) above ground than non-hyper accumulators growing in the same conditions, without showing any notice of symptoms in their tissues (Barceló and Poschenrieder,
2003). Nagaraju and Karimulla (2002) stated that plants such as Jatrophacurcas (from Euphorbiaceae), Dodonaea viscose (from Sapindaceae), and Cassia auriculata (from Fabaceae) can be applied to detoxify areas with trivial pollution of metal nutrients, organic matter, or contaminants as they had potential for remediation of soils polluted with different kinds of trace and major elements. Jatropha curcas belong to the family (Euphorbiaceae) which grows well under adverse climatic conditions because of its low moisture demands and tolerance to high temperatures (Augustus et al., 2002), have thecapability to grow in dry and poor soils and it also has the ability to scavenge heavymetals from wastelands (Majid et al., 2012; Zhang et al., 2013; Chang et al., 2014). This study thus, assessed the ability Jatropha curcas to accumulate and distribute heavy metals $(\mathrm{Cu}, \mathrm{Cd}, \mathrm{Pb}$, $\mathrm{Zn}, \mathrm{Cd}, \mathrm{Cr}$ and $\mathrm{Co}$ ) in their roots and shoots planted in dumpsite soil.

\section{MATERIALS AND METHODS}

Study Location:A pot experiment was carried out in Screen house of Forestry Technology Department, Federal College of Forestry, Ibadan, Oyo state. The experimental site lies between Latitude $7^{0} 26^{\prime} \mathrm{N}$ and Longitude $3^{0} 54^{\prime} \mathrm{E}$. The climate of the area is tropical. The annual rainfall ranges from $1400 \mathrm{~mm}-1500 \mathrm{~mm}$ 
and average relative humidity of about $65 \%$, the average temperature is $31.8^{\circ} \mathrm{C}$. (FRIN Meteorological Station, 2015).Topsoil used in this study was collected from a dumpsite located in Lapite village, within Akinyele Local Goverment area, Ibadan. It is situated between old Oyo road and newly constructed IbadanOyo express road (Fig.1). The dumpsite covers an area of 200 by 400 meters, sited on high elevation; weathered and fractured rocks (Akintola, 2014). Tones of wastes generated and collected from various locations in Ibadan and its environs are deposited on a daily basis onto the dumpsite, giving rise to large heap of waste of varying composition, up to $3.0 \mathrm{~m}$ high relative to the ground surface (Akintola, 2014). Lapite dumpsite and it's environ are underlained by Basement Complex rocks of Southwestern Nigeria. The major rock types in area and it's environ are migmatite and banded gneisses (Akintola, 2014). Composite topsoil was collected within the dumpsite and about $500 \mathrm{~m}$ lateral distance on the upslope side of the site at the depth of $0.20 \mathrm{~m}$. Topsoil collected within dumpsite is T1 while those collected from the upslope side of the dumpsite was control soil (T2). Soil sample was air-dried and sieved using $2 \mathrm{~mm}$ sieve to remove stones, roots and other materials that may be detrimental to the emergence of the young plants from the seeds.

Experimental method and Design:60 healthy seedlings was picked from germination boxes and transplanted into polythene pot of $30 \mathrm{~cm}$ by $15 \mathrm{~cm}$ containing $2 \mathrm{~kg}$ of soil at different treatment levels to ensure normal growth of the seedlings. The experiment consisting of three seedlings each in the two treatments, replicated ten times making a total of twenty (20) pots for the study and 60 seedlings. The pots were arranged in a completely randomized design and the experiment lasted for 12weeks (3 months). Growth parameters; plant height, stem diameter, Leaf area and leaf production were assessed fortnightly for three months. At the end of pot experiment, plant biomass was determined, soil samples before and after planting were collected and taken to the laboratory for chemical analysis.

Particle size and texture of soil samples were determined and soil $\mathrm{pH}$ was measured by means of a glass electrode $\mathrm{pH}$ meter by dipping the glass electrode into a 1:1 according to Thomas (1996). Soil organic carbon was determined by the chromic acid digestion method of Walkley and Black (Sparks, 2003). Plant parts (roots, stems and leaves) and soil samples were analyzed for heavy metal $(\mathrm{Cu}, \mathrm{Zn}, \mathrm{Pb}$, $\mathrm{Cd}, \mathrm{Cr}$ and $\mathrm{Co}$ ) concentrations using Inductively Couple Plasma Mass Spectrometry (ICP-MS) method.
Enrichment Factors (EF) and distribution Factors (DF) were calculated by using the equation 1 and 2 given by Chen et al., (2005):

$$
\begin{gathered}
E F=\frac{C_{\text {Plants }}}{C_{\text {Soils }}} 1 \\
D F=\frac{C_{\text {Plant shool }}}{C_{\text {plant root }}} 2
\end{gathered}
$$

Where $C_{\text {plants }}=$ concentration of heavy metals in plants; $C_{\text {plants }}=$ concentration of heavy metals in soils; $C_{\text {plant shoot }}=$ concentration of heavy metals in plant shoots; $C_{\text {plant root }}=$ concentration of heavy metals in plant roots

Analysis of variance (ANOVA) for the growth parameters and heavy metals concentrations in the samples were done using the Duncan's multiple range test DMRT $(\mathrm{p}=0.05)$ method. The statistical variations were considered significant at $p<0.05$. Data were computed using graphical methods.

\section{RESULTS AND DISCUSSION}

Physiochemical parameters of the potting media: Results of the physiochemical parameters of the soils used for this study are presented in Table 1. Particle sizes of the soils used were sand (73-79\%), silt (14$16 \%)$ and clay (10-13\%). The soils were sandy loamy and are suitable for seedling growth and development because it contains high nutrients, CEC and high water holding capacity. This is in line with similar work conducted on Cedrela odorota by Akintola and Bodede (2019). The $\mathrm{pH}$ of the soils after planting (5.16 -6.05) decreased when compared to soil before planting (5.99 - 6. 70). Since accumulation of chemical element in plants do not absolutely depend on their content in soil but also on the level of soil acidic-alkaline and reductive oxidative conditions and content of organic matter (Akintola and Bodede, 2019; Ovisagie and Ndiokere, 2008). Therefore, soil pH may affect the solubility and bioavailability of elements in the soil for plant uptake (Akintola and Bodede, 2019). Organic matter content (OMC) of the soils after planting were $(1.01-3.19 \%)$ while before planting were (2.31- 5.88\%). Highest organic matter content were recorded in T1 (dumpsite soil) than control and this can be attributed to decomposition and composting processes of the wastes deposited in the study area. Solid waste dumpsites are rich in organic matter which is the source of nitrogen and phosphorus which enhance soil fertility and promote plant growth (Akintola and Bodede, 2019). Concentrations of nitrogen $(0.28-0.62 \%)$ in T2 were higher than Control soil $(0.09-0.21 \%)$. Similar trend was observed in the concentrations of phosphorus in $\mathrm{T} 1$ 
and T2. Reduction in $\mathrm{pH}$, nitrogen, phosphorus and organic carbon content noticed in the soils after planting when compared to those at the onset of the experiment may be due to the effect of the plants growing in the media.

Table 1. Physiochemical parameter of the soils

\begin{tabular}{lllllllll}
\hline Treatments & Planting & $\mathrm{pH}$ & OMC $(\%)$ & $\mathrm{N}(\%)$ & $\mathrm{P}(\mathrm{mg} / \mathrm{kg})$ & Sand $(\%)$ & Silt (\%) & Clay $(\%)$ \\
\hline T1 & Before & 6.70 & 5.88 & 0.62 & 105.22 & 79.00 & 16.00 & 13.00 \\
& After & 6.05 & 3.19 & 0.28 & 87.22 & 75.00 & 14.00 & 11.00 \\
T2 & Before & 5.99 & 2.31 & 0.21 & 34.22 & 75.00 & 15.00 & 10.00 \\
& After & 3.16 & 1.01 & 0.09 & 25.99 & 73.00 & 16.00 & 11.00 \\
\hline
\end{tabular}

Growth performance of Jatropha curcas in potting media: Table 2 showed the effects of dumpsites contaminated soil on the growth performance of Jatropha curcas seedlings. Highest mean values of seedling height $(23.64 \mathrm{~cm})$, leaf area $\left(70.11 \mathrm{~cm}^{2}\right)$, stem diameter $(0.42 \mathrm{~cm})$, leaf production (16.88) and biomass production $(258.22 \mathrm{~g})$ were recorded from seedlings grown in dumpsite soil (T1) while lower values of seedling height $(18.22 \mathrm{~cm})$, leaf area $(54.22$ $\left.\mathrm{cm}^{2}\right)$, leaf diameter $(0.28 \mathrm{~cm})$, stem diameter $(0.42$ $\mathrm{cm})$, leaf production (11.27) and biomass production $(175.02 \mathrm{~g})$ were recorded in control soil (T2). These values are higher when compared with the study of Jatropha curcas seedlings grown in soil contaminated with varying amounts of spent engine oil (Akintola, 2019). The high values observed in the growth parameters of Jatropha curcas seedlings could be attributed to the soil being rich in organic matter whichis the source of most of the nitrogen and phosphoruswhich enhances soil fertility and promote plant growth (Ideriah et al., 2010). The biomass of the plant varied significantly. The results showed that biomass production for plants gradually increased with treatments (Table 2) indicating that the amounts of heavy metals in the soils did not affect biomass production or induce phytotoxicity symptoms in the plant (Akintola and Bodede, 2019).

Table 2. Growth performance of Jatrophacurcas in potting media

\begin{tabular}{llllll}
\hline Treatment & $\begin{array}{l}\text { Seedling } \\
\text { height, cm }\end{array}$ & $\begin{array}{l}\text { Leaf } \\
\text { Area, cm } \mathrm{cm}^{2}\end{array}$ & $\begin{array}{l}\text { Stem } \\
\text { Diameter, cm }\end{array}$ & $\begin{array}{l}\text { Leaf } \\
\text { production }\end{array}$ & $\begin{array}{l}\text { Biomass, } \\
\mathrm{g}\end{array}$ \\
\hline T1 & $23.65^{\mathrm{a}}$ & $70.11^{\mathrm{a}}$ & $0.42^{\mathrm{a}}$ & $16.88^{\mathrm{a}}$ & $258.22^{\mathrm{a}}$ \\
$\mathrm{T} 2$ & $18.22^{\mathrm{b}}$ & $54.22^{\mathrm{b}}$ & $0.28^{\mathrm{a}}$ & $11.27^{\mathrm{a}}$ & $175.02^{\mathrm{b}}$ \\
\hline
\end{tabular}

Heavy Metal Concentrations in potting media: Heavy metals concentrations in the treatment media before and after planting (BP and AP) are shown in Table 3. Heavy metal concentrations in dumpsite soils $\mathrm{Cu}$ (221.22 - 356.71), Zn (301.99 - 437.88), Pb (225.98 260.48), Cd (4.01 - 9.75), Co (14.61 - 27.22) and $\mathrm{Cr}$ $(15.89-30.11)$ were higher than those of control $\mathrm{Cu}$ (7.01 -48.01), Zn (6.22- 39.99), Pb (10.26-28.42), Cd (0.48 - 0.69), Co (7.09 - 16.89) and Cr (9.56 - 20.01) in $\mathrm{mg} / \mathrm{kg}$. The observed high heavy metal concentrations in dumpsite soils can be related to high deposit of metal- rich waste in the area (Akintola and Bodede, 2019). Heavy metal concentrations in soil before planting were found to be significantly higher than after planting. Heavy metals concentration in the soils are in the order of $\mathrm{Zn}>\mathrm{Cu}>\mathrm{Pb}>\mathrm{Cr}>\mathrm{Co}>\mathrm{Cd}$. Although the concentrations of these metals are higher in dumpsite soil and do require urgent clean up according to USEPA (2002), these amounts might contribute to human health risks (NYSDEC, 2006).

Table 3. Heavy Metal Concentrations in potting media

\begin{tabular}{llllllll}
\hline Treatments & Planting & \multicolumn{5}{c}{ Heavy Metals in $\mathrm{mg} / \mathrm{kg}$} \\
& & $\mathbf{C u}$ & $\mathbf{Z n}$ & $\mathbf{P b}$ & $\mathbf{C d}$ & $\mathbf{C o}$ & $\mathbf{C r}$ \\
\hline T1 & Before & 356.71 & 437.88 & 260.48 & 9.57 & 27.22 & 30.11 \\
& After & 221.22 & 301.99 & 225.98 & 4.01 & 14.61 & 15.89 \\
T2 & Before & 48.01 & 39.99 & 28.42 & 0.69 & 16.89 & 20.01 \\
& After & 7.01 & 6.22 & 10.26 & 0.48 & 7.09 & 9.56 \\
\hline
\end{tabular}

Heavy metal concentrations in root and shoot of Jatropha curcas: Mean concentration values of heavy metals determined in seedling parts (shoots and roots) of Jatropha curcas are presented in Table 4. Heavy metal concentrations in roots of the studied plants $\mathrm{Cu}$ (12.99 - 28.99), Zn (11.97 - 30.22), Pb (9.51 - 17.31), Cd (0.19 - 0.99), Co (6.01 - 8.56) and Cr (8.22 - 9.56) were lower than their concentrations in the shoots $\mathrm{Cu}$
(25.22- 46.21), Zn (26.09-48.01), Pb (11.46- 17.31), Cd (0.25 - 1.23), Co (9.22 - 12.98) and Cr (10.98 $14.01)$ in $\mathrm{mg} / \mathrm{kg}$. It was observed that Jatropha curcas accumulated significant amounts $\mathrm{Zn}, \mathrm{Cu}$ and $\mathrm{Pb}$ in their parts. Highest concentrations of these heavy metals were recorded in shoot than the root and this might be attributed to its importance in biochemical reactions especially in photosynthesis (Mohd et 
$a l ., 2013)$. The high concentrations of heavy metals in the shoots may indicate active translocation of these metals from roots to shoots. Heavy metals translocation to different plant part varies by species (Antosiewicz, 1992). The phenomena of high accumulation of metals in the roots apparently occur, as roots will also permit metal ions to pass through their system when taking up water and nutrients (Clemens et al., 2002). From the roots, dissolved metal ions will be translocated to other parts of plant (Punz and Sieghardt, 1993). Metal uptake by plants can be affected by several factors including metal concentrations in soils, soil $\mathrm{pH}$, cation exchange capacity, organic matter content, types and varieties of plants and plant age. It is generally accepted that the metal concentration in soil is the dominant factor (Adriano, 2000).

Table 4. Heavy metal concentrations in roots and shoots of Jatrophacurcas

\begin{tabular}{llllllll}
\hline Treatments & Planting & \multicolumn{5}{c}{ Heavy Metals in mg/kg } \\
& & $\mathbf{C u}$ & $\mathbf{Z n}$ & $\mathbf{P b}$ & $\mathbf{C d}$ & $\mathbf{C o}$ & $\mathbf{C r}$ \\
\hline T1 & Root & 28.99 & 30.22 & 17.31 & 0.99 & 8.56 & 9.56 \\
& Shoot & 46.21 & 48.01 & 22.59 & 1.23 & 12.98 & 14.01 \\
T2 & Root & 12.99 & 11.97 & 9.51 & 0.19 & 6.01 & 8.22 \\
& Shoot & 25.22 & 26.09 & 11.46 & 0.25 & 9.22 & 10.98 \\
\hline
\end{tabular}

Enrichment and Distribution Factors: The potential of Jatropha curcas seedlings to accumulate and transport metals was characterized by determining their enrichment factor (EF) and distribution factor (DF) in Table 5. Enrichment factors were lower in plant grown in dumpsite soils $(0.10-0.60)$ when compared to control soils $(0.39-1.92)$ and could be attributed to the higher concentration of heavy metals in the dumpsite soil and it will take a longer time for the plants to accumulate higher amount of it. But in the case of control soil, the concentrations of the heavy metals were lower, so the plants took the one it can tolerate within the time of the experiment (Akintola and Bodede, 2019). Thus, heavy metal uptake by plants from soil depends on the level of metal concentrations in the soil, time and other factors. Distribution factors (DF) of heavy metals from the root to shoot of Jatropha curcas plant's parts were high $(1.21-2.17)$ indicating the ability of the plants to accumulate heavy metal from the soil and distribute it to different parts of its tissue. The results showed that Jatropha curcas seedlings have low to high EF and this showed that the plants had great ability to uptake and subsequently translocate these metals in their parts. It was believed that Jatropha curcas seedlings varied in tolerance to heavy metals toxicity. Furthermore, their efficiency of extracting of heavy metals from soils is dependent on their concentration in the contaminated soil and the properties of the soil.

\begin{tabular}{lllll}
\multicolumn{2}{l}{ Table 5. Enrichment and Distribution Factors } \\
\hline Heavy & \multicolumn{2}{c}{ Enrichment } & \multicolumn{2}{l}{ Distribution } \\
Metals & \multicolumn{2}{l}{ Factors (EF) } & \multicolumn{2}{l}{ Factors (DF) } \\
& T1 & T2 & T1 & T2 \\
\hline $\mathrm{Cu}$ & 0.13 & 1.72 & 1.59 & 1.94 \\
$\mathrm{Zn}$ & 0.10 & 1.92 & 1.58 & 2.17 \\
$\mathrm{~Pb}$ & 0.10 & 0.92 & 1.31 & 1.21 \\
$\mathrm{Cd}$ & 0.24 & 0.39 & 1.24 & 1.31 \\
$\mathrm{Co}$ & 0.58 & 0.85 & 1.51 & 1.53 \\
$\mathrm{Cr}$ & 0.60 & 0.85 & 1.47 & 1.34 \\
\hline
\end{tabular}

Conclusion: The significant reduction observed in concentrations of heavy metals in soils before and after planting indicated their accumulation in the plant tissues. Low to high enrichment and high distribution factors proved the efficient of the plants for phytoextraction of metals from contaminated soils. The study had further proven the efficacy of Jatropha curcas for cleaning up of heavy metals in soils.

\section{REFERENCES}

Adriano, DC (2001). Trace elements in terrestrialenvironments: Biogeochemistry; Bioavailability andRisks of Metals. 2nd ed. Springer-Verlag New York,Berlin Heidelberg.

Akintola, OO (2019). Heavy Metal Uptake and Growth Response of Jatrophacurcas Linnaeus Seedlings in Spent Oil Contaminated Soil. Inter. J. Appl. Res.Technol., 8(2): 106 - 114.

Akintola, OO (2014). Geotechnical and Hydrogeological assessment of Lapite waste dumpsite in Ibadan, Southwestern Nigeria. Unpublished $\mathrm{PhD}$ Thesis. University of Ibadan, 307 pp.

Akintola, OO; Bodede, IA (2019). Distribution and Accumulation of Heavy Metals in Red Cedar (Cedrelaodorata) Wood Seedling Grown in Dumpsite Soil. J. Appl. Sci. Environ. Manage.23 (4): 811- 817.

Antosiewicz, DM (1992). Adaptation of plants to an environment polluted with heavy metal.ActaSocietatisBotanicorumPoloniae,61(2): 281-299.

Augustus, GDPS; Jayabalan, M; Seiler, GJ (2002). Evaluation and bioinduction of energy 
components of Jatrophacurcas. J. Biomass Bioenergy. 23: 161-164.

Barcelo, J; Poschenrieder, C (2003). Phytoremediation: Principles and Perspectives. Contributions to Science. 2: 333-334.

Brunet, A; Orr, SP; Tremblay, J; Robertson, K; Nader, K; Pitman, RK. (2008). Effect of post-retrieval propranolol on psychophysiologic responding during subsequent script-driven traumatic imagery in post-traumatic stress disorder. Journal of Psychiatric Research. 42(6):503-506.

Ceribasi, HI; Yetis, U (2001). Biosorption of Ni (II) and $\mathrm{Pb}$ (II) by Phanerochaetechrysosporium from a binary metal system-KineticsWater S.A 27(1) ·DOI: 10.4314/wsa.v27i1.5004.

Chang, CY; Yu, HY; Chen, JJ; Li. FB; Zhang, HH; Liu, CP (2014). Accumulation of heavy metals in leaf vegetables from agricultural soils and associated potential health risks in the Pearl River Delta, South China.Environ.Monit. Assess. 186(3):1547-1560.

Chen, SB; Zhu, YG;Hu, QH (2005). Soil to plant transfer of 238U, 226Ra and 232Th on U miningimpacted soil from southeastern China. J. Environ. Radioac. 82: 223-236.

Clemens S, Palmgren MG, Kraemer U. 2002. A long way ahead: understanding and engineering plant metal accumulation. Trends in Plant Science7: $309-315$.

Cook, RL, Hesterberg D (2013).Comparison of trees and grasses for rhizoremediation of petroleum hydrocarbons. Int.J.Phytorem. 15:844-860.

FRIN Meteorological Station (2015). Information on the climate condition on the study area.Forestry Research Institute of Nigeria, Ibadan.

Ghosh, M; Singh, S (2005). A review on phytoremediation of heavy metals and utilization of it's by products. Appl. Ecol. Environ. Res. 3(1): $1-18$.

Hernandez-Ochoa, I., Garcia-Vargas, G., LopezCarrillo, L., Rubio-Andrade, M., MoranMartinez, J., Cebrian, M. E. and QuintanillaVega, B. (2005). Low lead environmental exposure alters semen quality and sperm chromatin condensation in northern Mexico.Reproduce. Toxic.20:221-228.
Ideriah, TJK; Harry, FO; Stanley, HO; Igbara, JK (2010). Heavy metal contamination of soils and vegetation around solid waste dumps in Port Harcourt, Nigeria. J. Appl. Sci. Environ. Manage. 14 (1):101-109.

Kambhampati, MS; Vu, VT(2013). EDTA enhanced phytoremediation of copper contaminated soils using chickpea (Ciceraeritinum L.).Bull. Environ. Contam. Toxicol.91(3):310-313

NikMuhamad Majid, M. M. Islam, Melina E. Nap, Maryam Ghafoori; Arifin Abdu (2012). Heavymetal uptake and translocation by JusticiagendarussaBurm F. from textile sludge contaminated soil.ActaAgriculturaeScandinavica, Section B Soil \& Plant Sci. 62:2, 101-108

Meagher, R.B., 2000. Phytoremediation of toxic elemental and organic pollutants. Curr. Opin. Plant Biol., 3: 153-162.

Mohd, SN; Majid, NM; Shazili, NAM; Abdu, A (2013). Assessment of Melaleucacajuputiasheavy metals phytoremediator for sewage sludge contaminated soil. Am. J. Appl. Sci.10(9): 10871092.

Nagaraju, A; Karimulla, S (2002). Accumulation of elements in plants and soils in and around Nellore mica belt, Andhra Pradesh, India - A biogeochemical study. Environ Geol. 41: 852860.

New York State Department of Environmental Conservation (NYSDEC) (2006). Current situation in chronic wasting disease in New York. Available

URL: http//www.dec.state.ny.us/websitedfwmr/wildlife /deer/currentcwd/.html. Accessible at ml070120322.

Oviasogie, PO; Ndiokwere, CL (2008). Fractionation of lead and cadmium in refuse dump soil treated with cassava milling effluent. J. Agric. Environ. 9:10-16.

Pilon-Smiths, E (2005). Phytoremediation. Annu Rev Plant Biol., 56:15-39.

Punz, W; Sieghardt, H(1993). The response of roots of herbaceous plant species to heavy metals. Environ. Experi. Bot. 33(1):85-98 
Sparks, DL (2003). Environmental soil chemistry. Academic Press, UK.264 pp.

US-EPA (2002). Summary report: Remedial response at hazardous waste site. EPA-540/2-84 002a, Washington, DC.
Yruela, I (2005). Copper in Plants. Braz. J. Pla. Physiol., 17:145-156.

Zhang, Y. Y., Liu, J. H., Zhou, Y. M., Gong, T. Y., Wang, J., and Ge, Y. L. (2013b). Enhanced phytoremediation of mixed heavy metal (mercury)-organic pollutants (trichloroethylene) with transgenic alfalfa co-expressing glutathione S-transferase and human P450 2E1. J. Hazard. Mater. 206, 1100-1107. 